\title{
Two Mausoleums of Imperial Rome: New Insights From the Study of Non-Metric Traits of the Human Skull
}

\author{
A. Iorio ${ }^{1}$, A. Battistini ${ }^{1}$, F. De Angelis ${ }^{2}$, C. Caldarini ${ }^{1}$, \\ S. Di Giannantonio ${ }^{1}$, W. Pantano' ${ }^{1}$ P. Catalano ${ }^{3}$ \\ ${ }^{1}$ Collaborator of Soprintendenza Speciale per i Beni Archeologici di Roma, Via S. Apollinare 8, 00186 Rome, Italy. \\ E-mail: andreaiorio.uni2@gmail.com \\ 2 Department of Biology, University of Rome Tor Vergata, Via della Ricerca Scientifica 1, 00133, Rome, Italy \\ ${ }^{3}$ Soprintendenza Speciale per I Beni Archeologici di Roma, Via S. Apollinare 8, 00186 Rome, Italy
}

KEYWORDS: non-metric traits, Imperial Rome, familial grave.

\section{Introduction}

The epigenetic identification method is based on the observation of non-metric traits of the human skull and their frequencies observed in family contexts (Zupanic Slavec, 2004).

These variants seem to be the result of the expression of a polygenic complex whose phenotypic expressions are affected by epigenetic and environmental interactions (Gruneberg, 1963; Berry, 1968). The non-metric characters of the skull have been widely used to highlight the processes that affect the biological affinity between individuals (Bergman, 1993).

The purpose of this research is the analysis of the mausoleums of the necropolis Collatina and Casal Bertone (Rome, I-III century AD), in which the epigenetic identification method might be used to assess the biological affinity between individuals buried in the same funeral building. The mausoleum of the necropolis Collatina is externally surrounded by an area for the rituals (recinto) in which some burials have been discovered. The presence, in some cases, of male, female and child individuals in the same loculum inside the building allows to hypothesize the use of the building by a group of biologically related individuals, as suggested by the inscription found inside the mausoleum (De Angelis et al., submitted). Seventy-four individuals have been recovered inside the mausoleum of Casal Bertone: the presence of a male, a women and some children in the same burial, allows to hypothesize that each can contain a single family, even if enlarged. For this study the metric traits of the skull were used to identify biological similarities between individuals buried inside and outside the mausoleums.

\section{Materials and Methods}

The sample consisted of 106 skeletons: 53 pertained the necropolis Collatina ( 12 related to the mausoleum and
41 of the recinto) and 53 individuals from the funerary complex of Casal Bertone ( 30 are found in the mausoleum and 23 outside it). The selection of individuals was based on well-preserved skull. Thirty-two non metric characters (Hauser and De Stefano, 1989) have been selected depending on the accuracy and reproducibility of detection, performed by at least three operators. The differences between individuals inside and outside the mausoleums were initially assessed using Fisher's exact test. Two levels of data analysis were performed: the MMD (Mean Measure of Divergence) index has been calculated to test the significance of the comparison between the two communities (Sutter and Mertz, 2004); and the frequency of each character have been developed by the Correspondence Analysis (CA) and the Multiple Correspondence Analysis (MCA). The statistical analysis was performed using SPSS v.19.0 software. The Gower's similarity coefficient (Gower, 1971) was used to esteem the biological distance between individuals of the same necropolis. This index was performed using the software PAST v.2.09 (Hammer et al., 2001). The obtained distance values were used to built a cladogram based on the neighbor-joining method using PHILIP v. 3.69 (Felsenstein, 2009).

\section{Results}

The MCA (Fig. 1) shows the presence of a single cluster in which it is possible to note a slight distinction between the two communities. Indeed the burials of Casal Bertone are located only along a vertical axis to the left of the graph, while those of the necropolis Collatina are more variable. This result shows a substantial homogeneity between the two necropolis and can be explained by the negative value of the MMD (MMD = $\left.-0.0425 ; S_{M M D}=0.0360\right)$. Therefore, the frequencies of non-metric trait of the skull allow to consider the individuals of the two necropolis as a single sample of the population of Imperial Rome, in which it is possible to highlight specific subgroups that might differ in expression patterns of these morphological variations. 


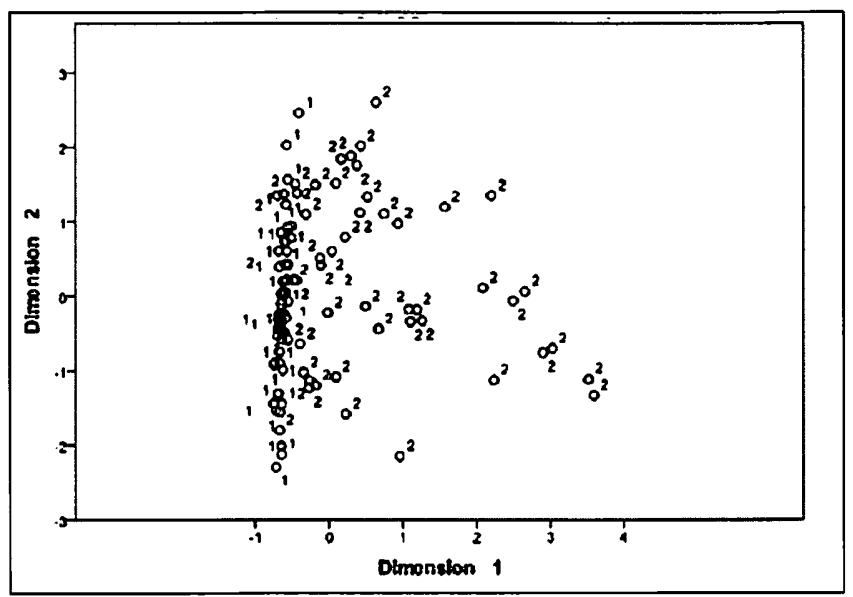

Fig. 1. MCA Casal Bertone-Collatina (95,9\%): 1 necropolis Casal Bertone, 2 necropolis Collatina.

The CA (Fig. 2) shows the relationships between internal and external burial of the mausoleums. A significant separation between the outside and inside burials the mausoleum of Casal Bertone, confirming the results obtained for the funeral building of the necropolis Collatina.

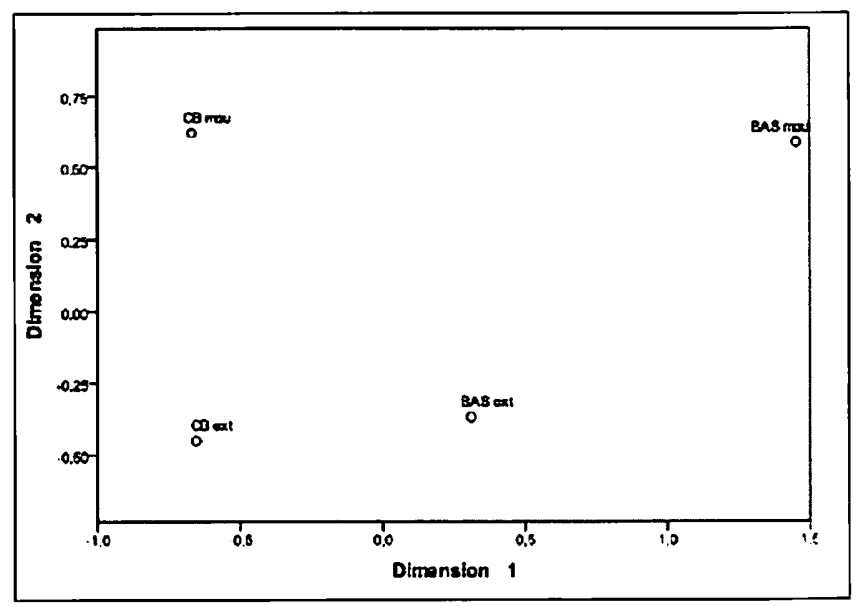

Fig. 2. CA Casal Bertone/Collatina (Dim. 1 70,7\%, Dim. 2 87,2\%, $p=0,000$ ).

The trees built by Gower's index are to visualize the biological distance between individuals of the same necropolis. The branches in bold indicate the biological similarity between individuals buried in the mausoleums of the two necropolis. This affinity analysis confirms through the $\mathrm{NJ}$-tree topology, the spatial distribution of individuals in MCA plot.

The presence, in other clades, of individuals buried in mausoleums, is a further indication of the extended character of the families constituting a single domus of the Imperial Rome.

In fact, as testified by numerous historical sources, the pater familias could grant the right of burial inside a funerary buildings to liberti or slaves, generally not biologically related to individuals making up the domus.

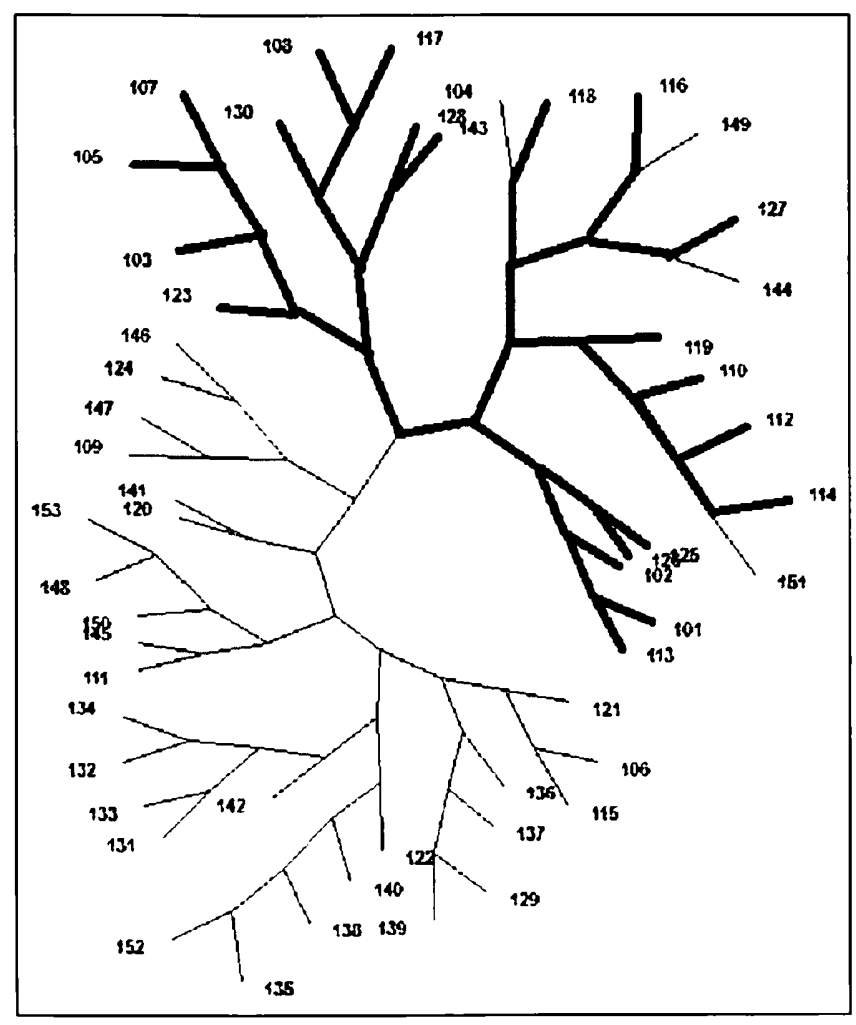

Fig. 3. NJ Casal Bertone, the numbers refers to every tomb.

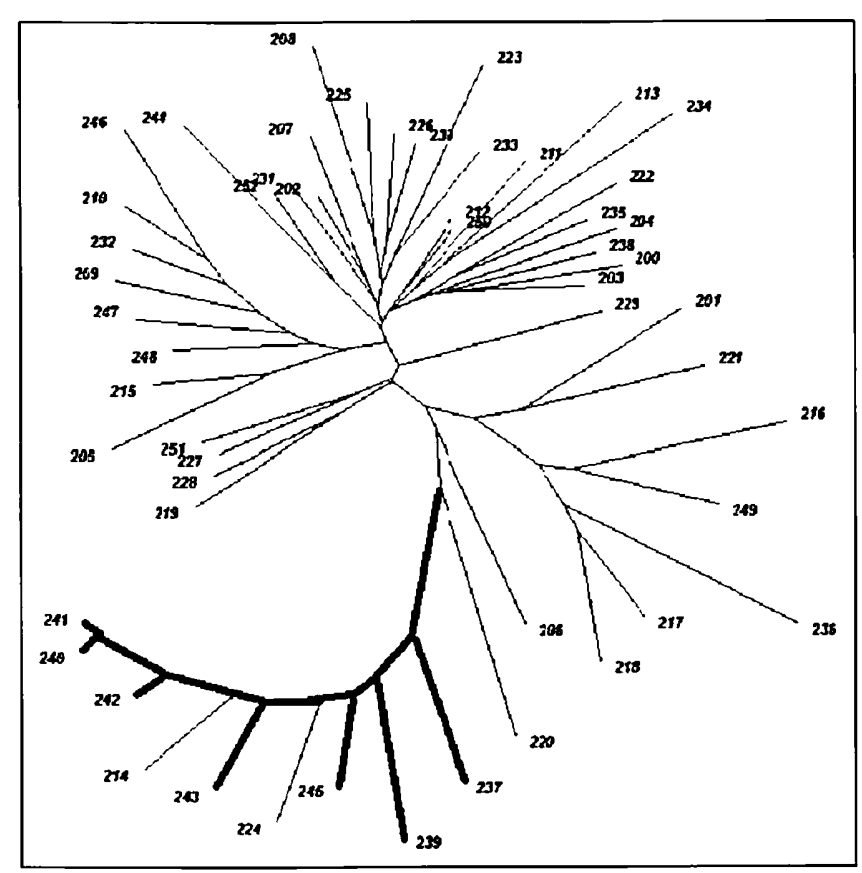

Fig. 4. NJ Collatina, the numbers refers to every tomb.

\section{Discussion}

The aim of the present study is to highlight cluster of biologically related individuals in the communities using non-metric traits as markers of the human skull. These characters are frequently employed to obtain useful information on history and the divergence of human populations (Carson, 2006). As this evaluation points out, these results might suggest these characters are good indicators of affinity between individuals, although their 
resolving power is moderately affected by ontogenetic and environmental components that affect them.

The integration of results with topographical data is effective in correctly understand the likely relationships between individuals. This study provides a basis for further confirmation of the hypothesis on the funeral customs of the Roman Imperial period and the use of particular monuments (mausoleums, graves, etc.) by a single domus.

\section{References}

Berry R.J. 1968. The biology of non-metrical variation in mice and men. In: Brothwell D.R. (eds.): The Skeletal Biology of Earlier Human Populations, Pergamon Press, Oxford: 103-133.

Carson E.A. 2006. Maximum likelihood estimation of human craniometric heritabilities. Am.J. Phys. Anthropol., 131: 169-180.

De Angelis F., lorio A., Battistini A., Caldarini C., Pantano W., Catalano P. 2012.An interesting mausoleum of the necropolis
Collatina (Rome, I-III century A.D.): new insights by nonmetric traits evaluation. Submitted to Int. J. Osteoarchoeol. Felsenstein J. 2009. PHYLIP (Phylogeny Inference Package) version 3.69. Distributed by theauthor. Department of Genome Sciences, University of Washington, Seattle.

Gower J.1971.A general coefficient of similarity and some of its properties. Biometrics, 27: 857- 871.

Gruneberg H. 1963. The Pathology of Development;A Study of Inherited Skeletal Disorders in Animals. Blackwell Publishers, Oxford.

Hammer Ø., Harper D.A.T., Ryan P.D. 2001. PAST: Paleontological Statistics Software Package for Education and Data Analysis. Palaeontologia Electronica, 4:9.

Hauser G., De Stefano G.F. 1989. Epigenetic Variations of the Human Skull. Schweizerbarts'sche Verlagsbuchhanlung (Nagele u. Obermiller), Stuttgart.

Sutter R.C., Mertz L. 2004. Nonmetric Cranial Trait Variation and Prehistoric Biocultural Change in the Azapa Valley, Chile. Am.J. Phys. Anthropol., 123: 130-145.

Zupanic Slavec Z. 2004. New method of identifying family related skulls. Springer Wien, NewYork. 